\title{
Influence of Different Time Intervals among the in-Office Bleaching Sessions on the Tooth Enamel Mass Variation
}

\section{Influência do Intervalo de Tempo Entre as Sessões de Clareamento Profissional na Variação de Massa do Esmalte Dental}

\author{
Ana Clara Portela de Almeida ${ }^{\mathrm{a}}$; Karoline Silva Barros ${ }^{\mathrm{a}}$; Mara Eliane Soares Ribeiro ${ }^{\mathrm{b}}$; Juliana Costa Pereira Baia \\ Mário Honorato Silva e Sousa Júnior ${ }^{c}$; Sandro Cordeiro Loretto*d \\ aUniversity Center of Pará. PA, Brazil. \\ ${ }^{b}$ Federal University of Pará, Stricto Sensu Graduate Program in Dentistry. PA, Brazil. \\ 'Federal University of Pará. PA, Brazil. \\ ¿Universitary Center of Pará. Federal University of Pará. PA Brazil. \\ *E-mail: sandroloretto@hotmail.com \\ Recebido em: 03/04/2019 Aprovado em: 27/06/2019
}

\begin{abstract}
This study evaluated the effect of different time intervals between tooth bleaching sessions on the variation of tooth enamel mass, using a 35\% hydrogen peroxide (HP35) gel. Twenty bovine incisor teeth were collected and cross-sectioned twice, leaving only the middle coronal portion. The dentin layer was removed, leaving only the buccal dental enamel. The samples were randomly divided into 2 groups ( $\mathrm{n}=10$ ): G1 (with a 7-day time interval between each bleaching session), and G2 (with a 2-day time interval between each bleaching session). Three bleaching sessions were performed for each group. Each specimen's mass was measured using an electronic analytical scale, first at the beginning of the experiments (T0), and then immediately after each bleaching intervention (T1, T2 and T3, respectively). All samples were stored in artificial saliva and kept in a biological chamber during the time of the study. The data analysis was performed using ANOVA for the related samples ( $\mathrm{p}$ $=0.05$ ). The results showed a reduction in the enamel mass values in $\mathrm{G} 2$ after the $3 \mathrm{rd}$ session when comparing to enamel mass values presented at the beginning of the study. On the other hand, G1 presented an increase in the mass values at the end of the third session, and these intragroup differences were statistically significant $(\mathrm{p}<0.001)$. It was concluded that bleaching treatment with 7 -day intervals between sessions leads to no tooth enamel mass loss, whereas the reduced 2-day time interval between sessions caused a significant tooth enamel mass loss.
\end{abstract}

Keywords: Tooth. Tooth Bleaching. Tooth Enamel.

\section{Resumo}

Este estudo avaliou a influência de diferentes intervalos de tempo entre as sessões de clareamento com peróxido de hidrogênio a 35\% (PH35) sobre a variação de massa do esmalte dental. Foram utilizados 20 dentes incisivos bovinos hígidos, seccionados em duas porções transversais, com a camada de dentina vestibular toda removida, restando apenas o esmalte dental vestibular. As amostras foram distribuidas em 2 grupos (n=10): G1 - intervalo de tempo de 7 dias entre as sessões de clareamento, e G2 - Intervalo de 2 dias entre as sessões de clareamento. Foram realizadas 3 aplicações de gel clareador em cada grupo. A pesagem dos espécimes foi realizada antes do início do tratamento clareador e ao final de cada intervenção clareadora, em uma balança analítica eletrônica. Os espécimes foram armazenados em saliva artificial, e mantidos em estufa biológica. Os dados foram submetidos à ANOVA para amostras relacionadas ( $p=0.05$ ). O G2 apresentou uma redução nos valores de massa do esmalte quando comparados os tempos antes do clareamento (T0 - 0.1650g) e após a $3^{\circ}$ sessão (T3 - 0.1643g). Entretanto, o G1 apresentou um aumento nos valores de massa ao término da terceira sessão (T0 - $0.1615 \mathrm{~g}$ e T3 - 0.1624g), sendo essas diferenças intragrupos estatisticamente significantes $(p<0.001)$. Foi possivel concluir que no clareamento com intervalo de 7 dias entre as sessões não houve perda de massa do esmalte dental, ao passo que quando reduzido o intervalo entre as sessões para 2 dias, uma perda significativa de massa foi observada.

Palavras-chave: Dente. Clareamento Dental. Esmalte Dentário.

\section{Introduction}

Nowadays and along of recent decades, aesthetics has become increasingly important in dentistry, based on the fact that many people find themselves unsatisfied with their smile, and wish to improve it ${ }^{1}$. The smile appearance associated to the teeth color, is one of the main concerns of such patients, and it leads to a huge demand for bleaching treatments, once it is relatively fast, and also considered one of the most conservative oral aesthetic procedures ${ }^{2}$.

Hydrogen peroxide is the most widely used agent for tooth whitening. It can be found in high concentrations (35-40\%), which is recommended for in-office tooth bleaching, or in low concentrations ( $5 \%$ to $10 \%$ ) for at-home tooth bleaching under professional supervision ${ }^{3,4}$. Modifications in tooth bleaching protocols, intending to optimize time by making the bleaching gel to work faster on the tooth surface, can result in damage to the enamel structure, such as resulting in erosion and / or porosity, changes in mineral content, as well as affect surface microhardness ${ }^{5-9}$, and such damages may be related to agent composition, concentration, $\mathrm{pH}$ values and different application techniques ${ }^{10}$.

Zimmer et al. ${ }^{11}$ verified the erosion of the dental enamel weighing the enamel mass. Another method for evaluating dental mass loss is the $3 \mathrm{D}$ non-contact perfilometry, which 
is valid for evaluation of superficial loss of the substrate, however, it does not provide any information of possible mineral loss in the underlying layers. Therefore, it is advisable to determine the enamel mass loss in bleaching studies by weighing the specimens, instead of using perfilometry tool, once, due to the low molecular weight of the peroxides, their diffusion within the underlying layers of the enamel, to break the chromatogenic macromolecules, is fundamental for the bleaching mechanism ${ }^{9,10}$.

A study of 2015, evaluated the effect of decreasing interval's time between clinical bleaching sessions on the risk and intensity of tooth sensitivity, using $35 \%$ hydrogen peroxide ( $35 \% \mathrm{HP})$, and concluded that reduction of the interval from seven to two days had similar teeth whitening response and, also, reduced the treatment time without increasing the bleaching-induced tooth sensitivity ${ }^{12}$. Nonetheless, an in vitro study of 2018 found that the reduction in time interval between sessions to 2 days might cause a decrease in microhardness and augment in roughness ${ }^{13}$.

The available literature on the possible deleterious effects on enamel structure when clinical sessions are performed in a shorter interval of time are still scarce $e^{13-15}$. Thus, it is necessary to elucidate if changing treatment duration, by reducing the interval between bleaching sessions, any damage can be observed, such as a pronounced enamel loss, even in presence of saliva (SA) that contains remineralizing agents. Therefore, the purpose of this study is to evaluate the influence of different time intervals ( 7 and 2 days) between clinical bleaching sessions on variation of tooth enamel mass.

\section{Material and Methods}

\subsection{Ethical aspects, sample collecting and characterization}

This study was subjected to the local Research Ethics Committee on Animals Use, and received an approval certification ( $\left.{ }^{\circ} 1286260317\right)$. As template for the experiments, twenty sound incisor bovine teeth from the Bos taurus indicus species were used. The teeth included in the research had 24 months average age, and all were erupted in the oral cavity, with a healthy crown and complete root formation.

After extraction, disinfection was made in $0.1 \%$ thymol solution for one week. The teeth were then stored in distilled water, renewed weekly, under refrigeration $\left(4{ }^{\circ} \mathrm{C}\right)$ until the time of the experiment, not exceeding 6 months of storage. Following, the teeth were analyzed under a stereoscopic microscope (40X) to detect the presence of cracks and / or fractures, which, if present, would eliminate the specimen from the study.

\subsection{Samples conditioning}

The teeth crowns were subjected to two transversal cuts (Figure 1). The first cut was made at a distance of $15 \mathrm{~mm}$, measured with a digital caliper (DIN 862; Mitutoyo, São Paulo, SP, Brazil) from the cementum-enamel junction and parallel to the incisal border. The second cut was performed at $5 \mathrm{~mm}$ from the cementum-enamel junction, thus obtaining a $10 \mathrm{~mm}$ tooth samples from the middle of the tooth crown portion. Thereafter, a longitudinal section in the mesio-distal direction was performed, in order to separate the buccal and lingual dental crown portions. The lingual portion and the root of each crown were discarded, and the buccal dentin layer was removed with the support of a conical truncated diamond burs \#4138 (KG Sorensen - Cotia, SP, Brazil) at high speed and under constant cooling, leaving only the buccal dental enamel surface. Then, all the samples were washed in an ultrasonic bath in distilled water for 20 minutes $^{16}$. Each enamel fragment was individually embedded in condensation silicone in circular polyvinyl chloride (PVC) matrices, measuring $20 \mathrm{~mm}$ in diameter to receive the bleaching treatment. The specimens were randomly divided into 2 experimental groups $(\mathrm{n}=10)$ (Table 1).

Figure 1 - A) Bovine Incisors of the species Bos Taurus indicus, markings of the dental crown performed at a distance of $15 \mathrm{~mm}$ and another at $5 \mathrm{~mm}$ of the amelocementary junction, resulting in fragments of the middle portion of the crown with an average height of $10 \mathrm{~mm}$. B) Direction transverse sections mesiodistal of the dental crowns. C) Removal of dentin with diamond Tip $\mathrm{n}^{\circ} 4138$ in high rotation and under refrigeration. D) Dental fragment after dentin layer removal.

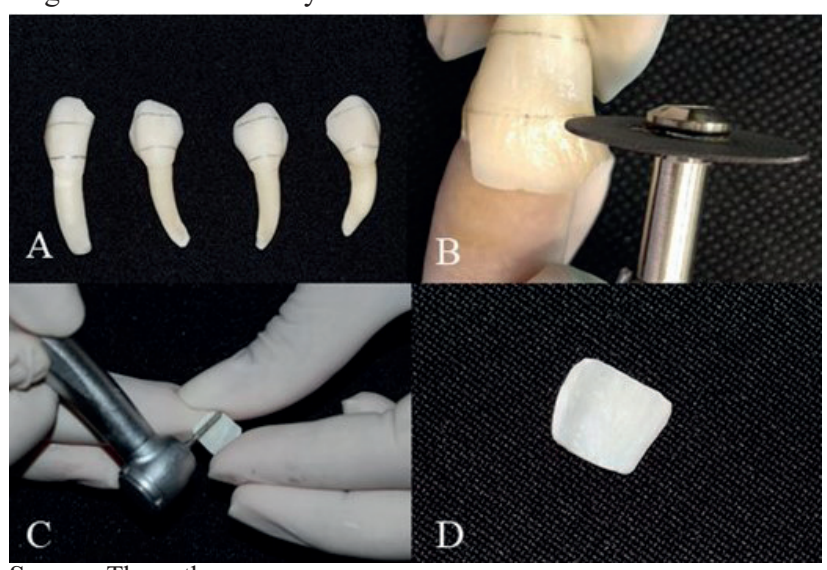

Source: The authors

Table 1- Division of experimental groups according to the intervention performed

\begin{tabular}{|c|c|}
\hline Group & Interval between the Dental Bleaching Sessions \\
\hline G1 & 7 days \\
\hline G2 & 2 days \\
\hline
\end{tabular}

Source: Research data.

\subsection{Tooth bleaching treatment}

The bleaching treatment was performed by using a $35 \%$ hydrogen peroxide $(35 \% \mathrm{HP})$ (Whiteness HP Blue, FGM, Joinville, SC, Brazil, Table 2), applied in a $1 \mathrm{~mm}$ thickness layer of bleaching gel, measured by aid of a millimeter periodontal probe on the surface of the sample. The bleaching gel was applied at the sample's surface and left on for 40 minutes in a single session (Figure 2). Along the bleaching session, an exploratory probe was used to mix the gel every 10 minutes, in order to eliminate possible bubbles resulting from the HP 
reaction, according to the manufacturer's recommendations. The specimens remained in the biological chamber $\left(37^{\circ} \mathrm{C}\right)$ during the bleaching session. After that, the gel was washed out from the enamel surface by an air/ distilled water spray (1 min), at a distance of approximately $5 \mathrm{~cm}$ from the sample's surface.

Figure 2. A) Inclusion of dental fragments in condensation silicone. B) Placement of the bleaching gel on the dental fragments in $1 \mathrm{~mm}$ thickness. C) After bleaching, the fragments were washed with distilled water in a triple syringe for 1 minute. D) Drying of the fragment for 2 minutes (time stipulated after pilot study) with air free of moisture and dirt. E) High precision balance used in the study. F) Measurement of the mass of the fragments with precision of 0.0001 grams

Source: The authors

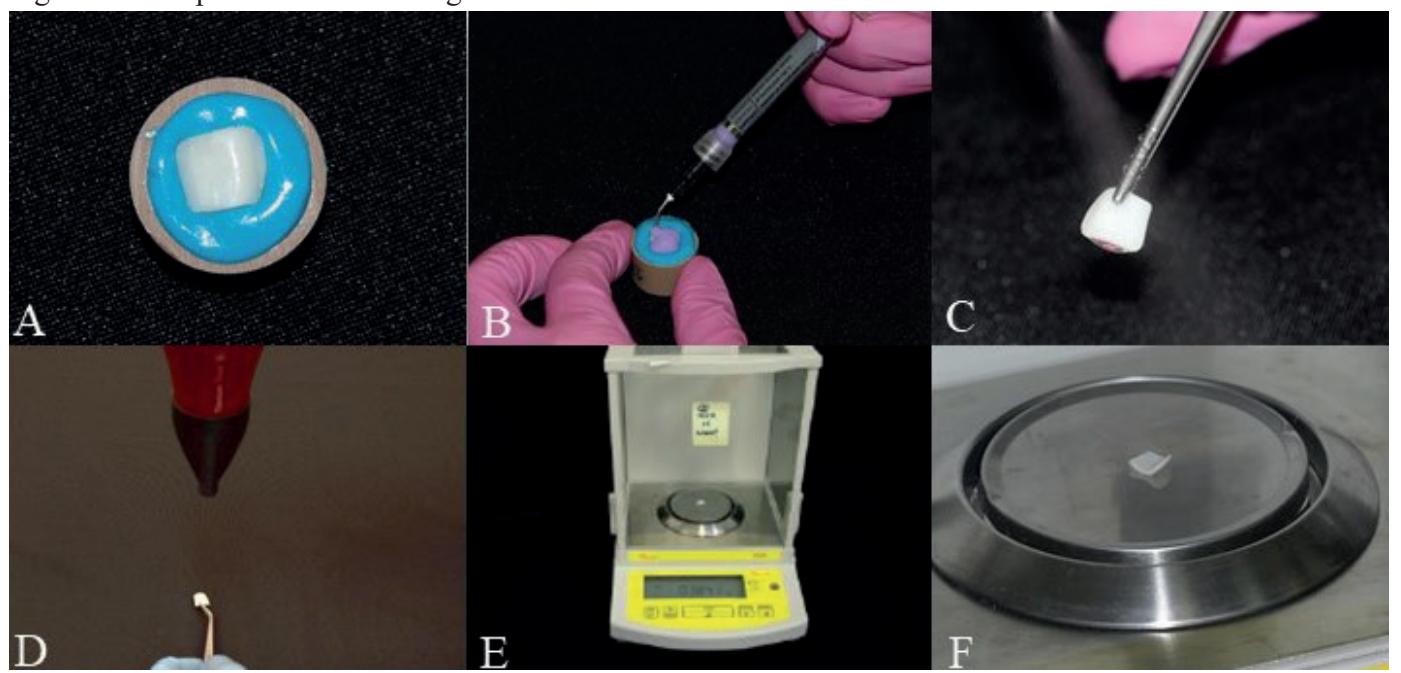

Table 2- Description of the materials used

\begin{tabular}{|l|l|l|}
\hline \multicolumn{1}{|c|}{ Materials } & \multicolumn{1}{|c|}{ Manufacture } & \multicolumn{1}{c|}{ Composition } \\
\hline $\begin{array}{l}\text { Bleaching gel - } \\
\text { Whiteness HP Blue }\end{array}$ & FGM - Joinville, SC, Brazil & $\begin{array}{l}35 \% \text { hydrogen peroxide, thickeners, violet inert pigment, neutralizing } \\
\text { agents, calcium gluconate, glycol and water. }\end{array}$ \\
\hline Artificial saliva & $\begin{array}{l}\text { A Fórmula - Compounding } \\
\text { Pharmacy, Belém, PA, Brazil } \\
\text { of potassium chloride, 10 mg of Nipagin, 24 mg of Sorbitol, 1270 mg } \\
\text { of potassium phosphate, 441 mg of calcium chloride, 4.5 mg of sodium } \\
\text { fluoride, 100 mg of Nipasol, 8 mg of Carboxymethylcellulose 3000 mL of } \\
\text { Distilled water }(\mathrm{pH}=7)\end{array}$ \\
\hline
\end{tabular}

Source: Research data.

\subsection{Enamel mass measurement}

After bleaching, the specimens were submitted to 60 seconds washing and dried with a Philco Titanium Travel dryer (Philco - Joinville, SC, Brazil) for 2 minutes, time enough to dry it all, and do not cause any change in the weight of the specimens, also considering that this equipment releases dirt-free air. The specimens were weighed at the following intervals: T0 - before the beginning of the bleaching treatment, T1 - at the end of the first bleaching session, T2 - at the end of the second bleaching session and T3 - at the end of the third and last bleaching session. For that, an electronic analytical scale (Quimis-AS 210, Diadema-SP-Brazil) was used, with a precision of 0.0001 , which provides the weight values in grams ${ }^{11}$. After weighing, the specimens returned to their respective containers and were kept in a biological chamber $\left(37^{\circ} \mathrm{C}\right)$, with the storage media renewed daily, until the next application of the bleaching gel. The bleaching procedure was repeated using the same protocol, until completion of three exposure sessions to HP35.

\subsection{Statistical analysis}

The data obtained were subjected to statistical analysis by using BioEstat ${ }^{\circledR}$ software, adopting a 5\% significance level. The samples had normal distribution (Shapiro-Wilk test) and the ANOVA test for the related samples was applied.

\section{Results and Discussion}

The means for enamel mass variation (and standard deviation) for each bleaching treatment session are shown in Table 3. The descriptive data analysis showed the highest mean value in G2 $(0.1653 \mathrm{~g})$, and the lowest mean value in G1 $(0.1615 \mathrm{~g})$, for T1 and T0, respectively. The ANOVA test indicated a significant statistical difference $(\mathrm{p}<0.0001)$ among all intragroup comparisons. For G1, which had 7-day interval between sessions, the values for enamel mass were increased up to the end of the second session of the bleaching treatment (T2 - 0.1629g). A decrease on enamel mass was observed after the third bleaching session (T3 $-0.1624 \mathrm{~g}$ ), but the mass value was still higher than in T0. Thus, it characterize an increase in the group mass mean value. For G2, which had a 2-day 
interval between each bleaching sessions, a slight increase in dental enamel mass was observed, when comparing it at the beginning of the experiment (T0 $-0.1650 \mathrm{~g})$, to the mean value at the end of the first bleaching session (T1 - 0.1653g). However, after that, the values kept decreasing up to the end of the $3^{\text {rd }}$ bleaching session (T3 - 1643g).

Table 3 - Difference between the mean and standard deviation of the mass variation in G1 and G2, in grams (g), of the dental enamel in T0- before bleaching, T1 - first bleaching session, T2 - second session of dental bleaching and T3 - third session of dental bleaching. Anova for related samples, adopting an $\boldsymbol{\alpha}$ level of significance $(\mathrm{P} \leq 0.05)$.

\begin{tabular}{|c|c|c|c|c|c|c|c|c|}
\hline & \multicolumn{3}{|c|}{ G1 - Seven-day interval among the session } & \multicolumn{3}{c|}{ G2 - Two-day interval among the sessions } \\
\hline \multirow{2}{*}{$\begin{array}{c}\text { Mean } \\
\text { (standard } \\
\text { deviation) }\end{array}$} & $\mathrm{T} 0$ & $\mathrm{~T} 1$ & $\mathrm{~T} 2$ & $\mathrm{~T} 3$ & $\mathrm{~T} 0$ & $\mathrm{~T} 1$ & $\mathrm{~T} 3$ & $\mathrm{~T} 3$ \\
\cline { 2 - 9 } & $0.1616 \mathrm{a}$ & $0.1619 \mathrm{~b}$ & $0.1629 \mathrm{c}$ & $0.1624 \mathrm{~d}$ & $0.1650 \mathrm{~A}$ & $0.1653 \mathrm{~B}$ & $0.1645 \mathrm{C}$ & $0.1643 \mathrm{D}$ \\
\cline { 2 - 9 } & $( \pm) 0.01$ & $( \pm) 0.02$ & $( \pm) 0.02$ & $( \pm) 0.02$ & $( \pm) 0.03$ & $( \pm) 0.03$ & $( \pm) 0.03$ & $( \pm) 0.03$ \\
\hline
\end{tabular}

$\mathrm{p}<0.0001$ Distinct letters indicate intra statistical difference.

Source: Search data.

The bleaching treatment with $35 \%$ hydrogen peroxide associated with calcium, was able to provoke variation in the enamel mass by changes on the enamel structure, in both G1 and G2 groups, but in different ways, though. The results in G1 demonstrated an enamel mass increase at the end of bleaching therapy, opposite behavior observed in G2, where at the end of the treatment had enamel mass loss.

Some studies have evaluated the weight of dental enamel mass through the erosive potential of some liquids ${ }^{11,17,18}$. However, the present study is the first to evaluate through this method the mass loss of dental enamel under bleaching therapy for in office protocol. A study that also used a $35 \%$ hydrogen peroxide, demonstrated that HP35 concentration diffuses more rapidly through hard dental tissues than the lower concentrations, thus, altering the structural and biochemical dental tissue properties ${ }^{19}$.

Oliveira and collaborators evaluated the properties of Knoop microhardness and roughness (Ra) after bleaching protocol using a 2-day interval between the sessions. Both properties had negative changes, drawing the attention to the large increase of roughness which directly interferes in the vitreous aspect of the enamel. The authors stated that the lower the saliva-enamel contact time between sessions (2 days), the lower the protective effect, which was visualized in the group with a 7-day interval ${ }^{13}$.

Another factor that may influence the surface characteristics of dental tissue is the acid $\mathrm{pH}$, still found in some bleaching gels, in order to ensure the stability of hydrogen peroxide ${ }^{20}$. The acid $\mathrm{pH}$ can change the dental superficial structure, resulting in greater surface roughness and increase the substrate porosity, which can cause points of tissue erosion ${ }^{21}$. However, in the current study the gel had an alkaline $\mathrm{pH}$, which may explain why there was no mass loss in G1, and perhaps preventing a greater loss in G2.

On the other hand, some studies have verified the occurrence of less roughness on dental enamel after bleaching treatment, that gave to the substrate a smoother surface, comparing to those ones which had not been exposed to peroxides $^{22-24}$. In this sense, a study using FT-IR spectroscopy found that a solution of $30 \% \mathrm{HP}$ caused severe morphological changes, such as dental enamel dissolution and significant calcium and phosphorus loss ${ }^{21}$. It is suggested, based on results that most superficial layer may have been lost, giving rise to a flatter underlying layer, a fact that may possibly explain the decrease of the final mass in G2. Thus, the dental enamel did not return to the baseline levels, after the adverse effects caused to its surface, probably due to reduced time in contact with saliva.

Studies have confirmed that calcium, phosphate, and fluorides present in human saliva have restorative effects on enamel, promoting the enamel remineralization when the teeth keeps contact with those compounds in the natural saliva ${ }^{16,25,26}$. Thus, the enamel mass increase observed in G1, in this study, may be explained by the saliva ability to replace the calcium and phosphate ions lost during a possible demineralization process caused by hydrogen peroxide.

Salomão et $\mathrm{al}^{22}$ evaluated the susceptibility to demineralization of bleached dental enamel subjected to different fluoride application regimes and showed that the use of hydrogen peroxide and carbamide peroxide (CP), both at $35 \%$, should be associated with a daily enamel fluoridation, otherwise, the in-office dental bleaching turn the tooth enamel more susceptible to demineralization. Therefore, the presence of calcium and/or fluoride in the bleaching gel composition, has the purpose of reducing the possible deleterious effects caused by high concentrated dental bleaching gels, in order to increase the incorporation of minerals into the dental enamel in an attempt to reduce adverse effects to the hydroxyapatite crystals $^{27,28}$.

Heshmat et al. ${ }^{29}$ comparing calcium phosphate to natural saliva and their effect on the hardness of bleached enamel, found out that both, the remineralizing agent (calcium phosphate) and the natural saliva were able to significantly increase the enamel microhardness, reduced during HP bleaching. Both calcium incorporated into the bleaching gel and saliva were present in this study.

Still corroborating this finding, another study from 2014, evaluated the effect of two HP35 bleaching agents, without and with calcium associated to treatment with acidulated or neutral fluoride. They demonstrated that the acidulated 
fluoride, combined with HP35 without calcium, caused a significant decrease in microhardness, whereas neutral fluorine associated to HP35 and calcium did not change the enamel microhardness ${ }^{25}$. Soon the incorporation of chemical components with remineralizing action becomes essential to avoid greater adverse effects to the dental enamel.

In addition, it is important to emphasize that in the oral cavity there are still other factors that can influence mass loss, such as the diet and dental brushing with abrasive toothpaste ${ }^{30}$. One study has shown that daily ingestion of some drinks, such as soda, is potentially more harmful to tooth enamel than the periodic application of peroxide bleaching agents ${ }^{31}$. Moreover, it was speculated that the enamel loss observed in this study is not clinically relevant when compared to the enamel periodically exposed to acidic beverages.

Considering the above, and the limitation of this in vitro study, it was observed that the dental bleaching with reduced time between the sessions, caused damage to the dental enamel, demonstrated by decrease of the mean value for dental mass in G2. Therefore, it is reasonable to infer that even with the fact that variation in the time interval between sessions does not cause or increase tooth sensitivity ${ }^{12}$, it can cause dental enamel damage that may not be reversible by the action of saliva and the addition of calcium into the bleaching gel $^{9}$.

\section{Conclusion}

The present study concludes that bleaching treatment with 7-day intervals between sessions leads to no tooth enamel mass loss, whereas the reduced 2-day time interval between sessions caused a significant tooth enamel mass loss.

\section{Acknowledgements}

The authors would like to thank CAPES for incentive to the study.

\section{References}

1. Kothari S, Gray AR, Lyons K, Tan XW, Brunton PA. Vital bleaching and oral-health-related quality of life in adults: A systematic review and meta-analysis. J Dent 2019;20(4):1220. doi: 10.1016/j.jdent.2019.03.007.

2. Kwon SR \& Wertz P. Review of mechanism of tooth whitening. J Esthet Restor Dent 2015;7(5):240-57. doi: $10.1111 /$ jerd.12152.

3. Rodrigues JL, Rocha PS, Pardim SLS, Machado ACV, FariaE-Silva AL, Seraidarian PI. Association between in-office and at-home tooth bleaching: A single blind randomized clinical trial. Braz Dent J 2018;29(2):133-139. doi: 10.1590/01036440201801726.

4. Alonso de la Peña V, López Ratón M. Randomized clinical trial on the efficacy and safety of four professional at-home tooth bleaching gels. Oper Dent 2014;39(2):136-43. doi: 10.2341/12-402-C.

5. Nascimento WC, Gomes YS, Alexandrino LD, Costi HT, Silva JO Jr, Silva CM. Influence of fluoride concentration and $\mathrm{pH}$ value of $35 \%$ hydrogen peroxide on the hardness, roughness and morphology of bovine enamel. J Contemp Dent Pract 2014;15(4):392-398. doi: 10.5005/jp-journals-10024-1550.

6. Parreiras SO, Vianna P, Kossatz S, Loguercio AD, Reis A. Effects of light activated in-office bleaching on permeability, microhardness, and mineral content of enamel. Oper Dent 2014;39(5):225-30. doi: 10.2341/13-031-L.

7. Magalhães JG, Marimoto AR, Torres CR, Pagani C, Teixeira SC, Barcellos DC. Microhardness change of enamel due to bleaching with in-office bleaching gels of different acidity. Acta Odontol Scand 2012;70(2):122-6. doi: 10.3109/00016357.2011.600704.

8. Sa Y, Sun L, Wang Z, Ma X, Liang S, Xing W, et al. Effects of two in-office bleaching agents with different $\mathrm{pH}$ on the structure of human enamel: an in situ and in vitro study. Oper Dent. 2013;38(1):100-10. doi: 10.2341/11-173-L.

9. Klaric E, Rakic M, Sever I, Milat O, Par M, Tarle Z. Enamel and dentin microhardness and chemical composition after experimental light-activated bleaching. Oper Dent 2015;40(4):132-41. doi: 10.2341/14-148-L.

10. Fátima Carvalho Vasconcelos M, Fonseca-Gonçalves A, França AKA, Medeiros UV, Maia LC, Queiroz CS. An in vitro evaluation of human enamel surfaces subjected to erosive challenge after bleaching. J Esthet Restor Dent 2017;29(2):128-36. doi: 10.1111/jerd.12277.

11. Zimmer S, Kirchner G, Bizhang M, Benedix M. Influence of various acidic beverages on tooth erosion. Evaluation by a new method. Plos One 2015;10(6): e0129462. doi: 10.1371/ journal.pone.0129462.

12. De Paula EA, Nava JA, Rosso C, Benazzi CM, Fernandes $\mathrm{KT}$, Kossatz S, et al. In-Office bleaching with a two- and seven-day intervals between clinical sessions: A randomized clinical trial on tooth sensitivity. J Dent 2015;43:(4)424-29. doi: 10.1016/j.jdent.2014.09.009.

13. Oliveira RP, Baia JCP, Ribeiro MES, MHS Souza Júnior, Loretto SC. Influence of time intervals between bleaching procedures on enamel microhardness and surface roughness. Open Dent J 2018;12(1):555-9. doi: $10.2174 / 1874210601812010555$.

14. Reis A, Tay LY, Herrera DR, Kossatz S, Loguercio AD. Clinical effects of prolonged application time of an in-office bleaching gel. Oper Dent 2011;36(6):590-6. doi: 10.2341/10173-C.

15. Kossatz S, Martins G, Loguercio AD, Reis A. Tooth sensitivity and bleaching effectiveness associated with the use of a calcium containing in-office bleaching gel. J Am Dent Assoc 2012;143(12):81-7.

16. Vilhena KFB, Nogueira BCL, Fagundes NCF, Loretto SC, Angelica RS, Lima RR, et al. Dental enamel bleached for a prolonged and excessive time: Morphological changes. PLoS One 2019;14(4):e0214948. doi.org/10.1371/journal. pone. 0214948

17. Von Fraunhofer JA, Rogers MM. Dissolution of dental enamel in soft drinks. Gen Dent. 2004;52(4):308-12.

18. Von Fraunhofer JA, Rogers MM. Effects of sports drinks and other beverages on dental enamel. Gen Dent 2005;53(1):2831.

19. Sato C, Rodrigues FA, Garcia DM, Vidal CMP, Pashley $\mathrm{DH}$, Tjäderhane L, et al. Tooth bleaching increases dentinal protease activity. J Dent Res 2013;92(2):187-92. doi: $10.1177 / 0022034512470831$

20. Xu B, Li Q, Wang Y. Effects of $\mathrm{pH}$ values of hydrogen 
peroxide bleaching agents on enamel surface properties. Oper Dent 2011;36(5):554-62. doi: 10.2341/11-045-1.

21. Bistey T, Nagy IP, Simó A, Hegedus C. In vitro FT-IR study of the effects of hydrogen peroxide on superficial tooth enamel. J Dent 2007;35(4):325-30. doi: 10.1016/j.jdent.2006.10.004

22. Salomão D, Santos D, Nogueira R, Palma-Dibb R, GeraldoMartins V. Acid demineralization susceptibility of dental enamel submitted to different bleaching techniques and fluoridation regimens. Oper Dent 2014;39(4):178-5. doi: 10.2341/13-140

23. Faraoni-Romano JJ, Da Silveira AG, Turssi CP, Serra MC. Bleaching agents with varying concentrations of carbamide and/or hydrogen peroxides: effect on dental microhardness and roughness. J Esthet Restor Dent 2008;20(6):395-402. doi: $10.1111 / \mathrm{j} .1708-8240.2008 .00216$. x.

24. Cvikl B, Lussi A, Moritz A, Flury S. Enamel surface changes after exposure to bleaching gels containing carbamide peroxide or hydrogen peroxide. Oper Dent 2015. doi: 10.2341/15-010-L.

25. China AL, Souza NM, Gomes Ydo S, Alexandrino LD, Silva CM. Effect of fluoride gels on microhardness and surface roughness of bleached enamel. Open Dent J 2014;14(8)18893. doi: 10.2174/1874210601408010188.
26. Cvikl B, Lussi A, Moritz A, Flury S. Enamel surface changes after exposure to bleaching gels containing carbamide peroxide or hydrogen peroxide. Oper Dent 2016b;41(1):3947. doi: 10.2341/15-010-L.

27. Moreira RF, Santos FP, Santos EA, Dos Santos RS, Dos Anjos MJ, de Miranda MS. Analysis of the chemical modification of dental enamel submitted to $35 \%$ hydrogen peroxide "in-office" whitening, with or without calcium. Int J Dent 2017:4646789. doi: 10.1155/2017/4646789.

28. Mellgren T, Qin T, Öhman-Mägi C, Zhang Y, Wu B, Xia W, et al. Calcium phosphate microspheres as a delivery vehicle for tooth-bleaching agents. J Dent Res 2018;97(3):283-8. doi: $10.1177 / 0022034517741295$.

29. Heshmat H, Ganjkar MH, Miri Y, Fard MJK. The effect of two remineralizing agents and natural saliva on bleached enamel hardness. Dent Res J 2016;13(1):52-7. doi: 10.4103/17353327.174713 .

30. Engle K, Hara AT, Matis B, Eckert GJ, Zero DT. Erosion and abrasion of enamel and dentin associated with at-home: an in vitro study. J Am Dent Assoc 2010;141(5):546-51.

31. Grobler SR, Majeed A, Moola MH. Effect of various tooth-whitening products on enamel microhardness. SADJ 2009;64(10):474-9. 